\title{
KATEGESE IN DIE WEEK
}

\author{
DS. H. N. BOTHA
}

\section{INLEIDING:}

In die Kerk se algemene opvatting en rigting met dis behartiging van die kategese, is dit baic duidelik dat diz Kerk klaar getuies het vir die baginsel van 'n onafskeidbare verbondenheid van dic kategese met dic crediens. Die kategesc wil uit die crediens voortvloei en weer daarheen terugvoer, as paraliturgiese element van dic Kerk se verkondiging.

Hierdie opvatting impliseer dat die kategese tussen erediens cn crediens as funksionerencle verkondigingsgestalte van die Kerk bchartig wil wees deur dicgəne wat daarvoor verantwoordelik is.

Dit is ook reeds duidelik uitgemaak dat die kategese werk van die Kerk (amptelikc kerkwerk) en die onontduikbare verantwoordelikheid van die doopouers is.

Hierdie verantwoordelikheid sal daarom in onderlinge samchang met die regte begrip en as eenheid die een gemeenskaplike doelwit en bestemming in die oog moet hê, naamlik die geloof in Jesus Christus.

\section{SAMEHANG TUSSEN KERK EN DOOPOUER SE VERANT- WOORDELIKHEID BY DIE KATEGESE IN DIE WEEK:}

Die kategese word varrig op grond van die feit dat die Heilige Skrif hierdie saak as duidelike opdrag bevat.

In die Heilige Skrif word reeds in dic Ou Testament gestal dat dit die heilige God is wat uit louter genade Sy verbond oprig met die mens om vir hom 'n God te wees on vir sy nageslag na hom.

1. Sy verbondsgenade moet in elke nuwe tyd weer oorvertel cn verkondig word. Hierclic oorvertelling van God se heil is 'n gawe van God aan dic mıns waardeü $\mathrm{Hy}$ die geskiedenis sinvol maak.')

In hierdie verband is die ouer die persoon aan wie van die Here 'n bevel uitgaan ,.... en leer dit aan julle kinders, deur daaroor te spreek as jy in jou huis sit en as jy op pad is en as jy gaan lê en as jy opstaan ....”)

1) Genesis 17:7.

2) Deuteronomium 11:(18-22); 6:4v; Psalm 78:3-8. 
'n Verdere eis van God word as voorwaarde aan die ouer gestel vir uitvoering van bogenoemde opdrag, naamlik „Hoor Israel die Here Onse God is 'n enige Here. Daarom moet jy die Here jou God liefhê met jou hele hart en met jou hele siel en mct jou hele krag.":")

Die gelowige oorvertelling van die ouer moet tot gevolg hê dat die kind ook daardeur aangegryp word, sodat die kind ook self kan ondersoek.

„As jou seun jou later vra en sê: Wat beteken die getuienisse en die insettinge en die verordeninge wat die Here Onse God julle beveel het? dan moet jy aan jou seun sê: Ons was slawe van Farao in Egipte maar die Hare het ons deur 'n sterke hand uit Egipte uitgelei."4)

In die Ou Testament word die woord (lemeed) gebruik vir onderrig in verband met die wil van God, soos dit openbaar word onder en vir die mense. En hierdie bekendwording van Sy wil deur die onderrig beteken ook onvoorwaardelike beslaglegging op die mens vir God.

Die woord Katechein wat in die Nuwe Testament gebruik word en wat ons met "ond ərrig" vertaal beteken letterlik „om van bo af te laat klink"; dit wil sê om met gesag te leer.

Die kategese is dus die onderrig wat die openbaring van God wil laat klink in die ore van hulle wat onderrig word, sodat deur Sy openbaring waarmee hulle toegerus word hulle tot geloofsgehoorsaamheid en 'n Christelike lewenswandel, gebring kan word.

Kategese om dit te bcoefen, is dus die oorplanting van die geloof (Kerkwees). Die Bybel gebruik deurgaans die woord lategese as 'n middel waardeur die saligmakende geloof in Jesus Christus tot stand gebring word.

In Luk. 1:1-4, Lukas vir Theófilus, dat hy in Sy Evangelie die corgelewerde geloof in Jesus Christus beskrywe, sodat Theófilus met volle sekerheid kan weet die dinge waaromtrent hy gekatkiseer is. En hierdie dinge waarin Theófilus gekatkiseer is, (naamlik dic geboorte, lewe, lyding, dood, opstanding en hemelvaart), hierdic dinge aangaande Jesus Christus wat geglo moet word, word alles meegedeel in die regte volgordz, dit wil sê in die volle omvang en in dic regte samehang, vant só is dit die dinge waarin Theófilus gekatkiseer is.

:) Deuteronomium 6:4-5.

4) Deuteronomium 6:20-21. 
Lukas vermeld nie alleen die feite nie, maar gee ook 'n verklaring van die heilsfeite, byvoorbeeld by die lofsang van Maria. ${ }^{5}$ )

Vir Lukas bestaan die Evangelie daarom uit feitemededeling en uitleg van die betekenis van hierdie feite. Volgens Prof. De Wet is: „Hierdie weg van mededeling van heilsgeskiedenis plus uitleg van die betekenis van die heilsgeskiedenis (is) die kategetiese weg wat uitloop op stigting en versterking van die geloof. Want die volle sekerheid waarmee Theófilus hierdie dinge moet weet, is die sekerheid van die geloof."')

Ook in die boek Handelinge word vertel van Apollos wat ,gekatkiseer" is in die weg van die Here sodat hy tot geloof in Jesus Christus gekom het.

Uit bostaande is dit daarom duidelik dat kategese die middel is waardeur mense die saligmakende geloof in Jesus Christus ontvang en in daardie selfde geloof gehou en versterk word.')

Die kategese in die lewe en werk van die Reformatoriese Kerk stuur daarom ook af op 'n duidelike rekenskap van die geloof in Jesus Christus, by die aflegging van die geloofsbelydenis in die openbaar nadat noukeurig onderrig is en ondersoek is.

Kategese as amptelike taak van die Kerk en as ouerplig wil daarom deur Kerk en ouer beoefen word en behartig word asof dit mense wil bring by die geloof in Jesus Christus. En as die lewende geloof die mikpunt en bestemming van die kategese is, dan sal elke kategeet en gedoopte vanuit die bepaalde middelpunt (sentrum) van die Kerklike verkondiging, naamlik die erediens, (waar die woord reg gespreek en die Sakramente bedien word volgens die instelling van Christus) die kategese moet beoefen en deurloop. Hierdie geloof word in ons gewerk en versterk deur die gehoor van die gepredikte woord en die gebruik van die heilige Sakramente. ${ }^{8}$ )

Die kategese word ook verrig as gevolg van die feit dat mense gedoop is. Die kategese is daarom nasorgwerk, werk op dit wat uit die erediens voortkom, naamlik die Doop.

Tereg verstaan die Kerk ook die Kategese in die Kerkwet as onderrig as gevolg van die doop: $\left.{ }^{9}\right)$

5) Lukas 1:45-56.

6) Inleiding tot die Kategese bls. 2 (iii) - Prof. J. I. de Wet.

i) Handelinge 18:24-28.

8) Kort Begrip, bls. 62, Vraag 48-50.

9) Kerkwet, Hoofstuk 9, Artikel 90(i). 
„Die kategese het tot doel om die jeug van die kerk en hulle wat tot die Kerk wil toetree, te onderrig aangaande die Leer van die Kerk en die betekenis van hulle dooplidmaatskap van die Kerk waarin hulle opgeneem is deur die doop, om hulle voor te berei vir die deelname van medeverantwoordelikheid vir die opbou van die Godsryk in die algemeen en van die Nederduitsch Hervormde Kerk in die besonder."

Behalwe die nasorg op die gebeure van die doop wil die kategese ook voorsorg wees sodat die gedooptes as bewuste en meelewende gelowiges sal saamwerk tot die opbou en groei van die Godsryk. Daarom wil die kategese in sy voorsorgtaak sorg dat die gedoopte sal kom onder die ander elemente van die verkondiging by die EREDIENS waar God deur die uitleg en toepassing van Sy heilswaarhede hierdie geloof wil vermeerder en versterk.

Die kategese is met die gedoopte op weg vanaf die Doop (wat in die erediens ontvang is) na elke erediens van elke Sondag en op weg na die ander sakrament, die Nagmaal (wat ook in die erediens ontvang word).

Dit lê daarom voor die handliggend dat as gedooptes vanaf die doop tot by die openbare beloofsbelydenis steeds ontmoet word met die verkondiging in die erediens en in die kategese, ciaar ook ná die geloofsbelydenis sò 'n voortgesette, gewillige en dankbare ontmoeting ongntbeerlik sal voortduur. Want die kategese beteken mos nie om alleen skoolse feite tuis te bring nie, maar om die gedoopte ook te leer om tuis te wees onder die elemente van dic verkondiging waardeur God die geloof wil bou en versterk deur Sy Heilige Gees. So word hulle medeverantwoordelikheid vir die opbou van die Godsryk tuisgebring. Die Kerkwet het in bogenoemde artikel, ${ }^{10}$ ) duidelik in die oog dat katkisante ook 'n lewensvorming moet ondergaan. Die kategese as verkondiging van die Kerk sal daarom, as dit die katkisant hierdie lewensvorming vanuit die erediens NA die erediens toe wil laat ondergaan, 'n PLEK MOET vind in die week waar daar gelewe en gewerk word, - vanuit Sondag se erediens na die rolgende erediens toe.

\section{GEVOLGTREKKING:}

Uit bostaande blyk dus die volgende:

(a) Die opdrag om te onderrig uit Ou en Nuwe Testament blyk onderrig te wees wat die middel wil wees om die salig. makende geloof in Jesus Christus te laat ontvang.

I") Kerkwet, Artikel 90(i), Hoofstuk 9. 
(b) Die kategese wil as nasorg en voorsorg op die gebeure wat voortkom uit die erediens, nie die erediens vervang nie, maar in ' $n$ paralelle funksionele plek met die prediking en sielsorg steeds afstuur op die erediens met die Nagmaal as bestemming.

(c) Die kategese beoog, 'n plek in die week om sy lewensvormende funksie te vervul daar waar die gedoopte lewe en werk.

\section{HOE MOET DIE AMPTELIKE KATEGESE DIE DOOPON- DERRIG VAN DIE OUER AANVUL?}

Soos reeds gestel is, lê die behartiging van die Kategese in die praktyk van die Kerklike lewe in die hand van die doopouer en die Kerk.

(i) Gesien die doel van die kategese, naamlik diê geloof in Jesus Christus, is dit vanselfsprekend dat die Kerk verantwoordelikheid het om mense te roep tot belydenis van die geloof in die Drie-Enige God. Daarom spreek dit vanself dat die Kerk sal voorskryf wat in die katkisasie behandel sal word. (Kerkwet Art. 17).

In Hoofstuk 9, Artikel 93(2) bepaal die Kerkwet vir voorb乞reiding tot die Openbare geloofsbelydenis dat die volgende materiaal behandel moet word:

(a) Geloofs- en sedeleer.

(b) Bybelse geskiedenis.

(c) Die Kerkboek.

(d) Kerkgeskiedenis.

(e) Die kennis van en oefening in die sing van Psalms $\mathrm{cr}$ Gesange.

(ii) Daar die Kategese dooponderrig is en die doopouers direk betrokke is as gelowiges deur die doopbelofte by hierdie onderrig, daarom sal daar duidelikheid moet bestaan met betrekking tot dit wat die inhoud van hierdie onderrig sal wees.

By die 3 vrae waarby die doopouers hom verbind voor God en die Kerk tot hierdie onderrig blyk dit duidelik, dat die doopouer dit onderneem in geloof, saam die Kerk en soos die Kerk met die voorneme om te onderrig of te laat onderrig. Hierdite voorneme en belofte word onderneem saam met die Kerk en dis doopouer wil en sal sy onderrig in onlosmaaklike samehang met die Kategese van die Kerk moet verrig. Daarom sal die materiaal dieselfde moet wees omdat die doelwit vir albei die geloof in Jesus Christus is. 
Al die afdelings wat die Kerk nodig ag vir 'n behoorlike kategetiese onderrig sal vir die Kerk en die doopouer belangrik en onontbeerlik moet bly, want elke afdeling staan op sy eie wyse in diens van die kategese wat 'n „opregte geloof" beoog.

Hierdie opregte geloof is volgens Vraag en Antwoord (19 van die Kort Begrip): ". . . . 'n Sejkere kennis van God en sy beloftes, wat vir ons in dis Evangelie geopenbaar is, en 'n hartlike vertroue dat al my sondes om Christus ontwil vergewe is."

Die verantwoordelikheid van die Kerk en doopouer sal wat die stof aanbetref daarom nie geskei kan word nie. Kennis en vertrouc (opregte geloof - Vraag 19 Kort Begrip) sal deur beide ingeskerp moet word. Dit sal alleen langs èèn weg sinvol kan gebeur, en dit is naamlik as hierdie kennis en vertroue vanuit die erediens in die eerste plek geleer word.

Dic bybring van feitekennis en vertroue kan sekerlik met die beoogde perikope-indeling met onderlinge samehang goed vlot. Wanneer die gesinslewe gedurende die week by huisgodsdiens en andersins geborduur word rondom 'n bepaalde bybelgedeelte wat deur die gedooptes geleer word met die oog op Sondag se erediens en kategese, dan word die bybring van feitekennis gedurende die ouer se onderrig in die week in 'n hoë mate afgehandel. In Sondag se erediens word oor hierdie selfde gedeelte dan gepreek (dit wil sê uitgelê en toegepas). (Terloops die Perikope-indeling sal ook vereis 'n aanpassing van die Bybelse Dagboek wat die Stof aanbetref). Daarna word by die amptelike kategese gekontroleer of die oncierrig van die ouer gedurencle die week en die prediking vaste kennis van die gedoopte geword het.

So mag die Kerk sekerlik biddend verwag dat hierdie „regte" kennis, wat vaste kennis geword het, sal uitloop op vertroue en geloof.

Die amptelike kategese in die Kerk sal daarom nooit die kategese vir die loopouer mag vervang of uit die hand neem nie, maar steeds moet aanvul en verleng.

Die kategese het ook 'n lewensvormende funksie omdat dit nasorg wil doen aan die gedooptes deur hulle hulle doop te leer verstaan en terselfdertyd die voorsorg tref dat daardie dopeling weer in die erediens kom, waar hy weer die avondmaal kan ontvang.

As ons nou in 'n mate wil vasstél of die katkisant die dinge wat hy in die kategese geleer het, sy eie gemaak het, dit opgeneem het in sy hart en lewe, dan sal dit ook gesien kan word aan sy bywoning van die erediens. So ontvang die Kerk ook vir 
homself ' $n$ gegewe maatstaf waaraan die lewensvormende taaik van die kategese gemeet kan word, rondom die Evangeliewoord.

Die harde feit dat mense in die Kerk buitekerklik is vanaf die dag van geloofsbelydenis (deur hulle veragting vir God, Sy Woord en Sy Sakrament) - laat 'n N.B.-vraagteken staan oor die Kategese van die Kerk en ouer ten opsigte van hulle wat gedoop is en deur die kategese by Woord en Sakrament juis tuisgemaak moes gewees het.

As bogenoemde situasie ' $n$ onweerlegbare feit is in die lewe van elke gemeente, sal die doopouer moet besluit of die kategese in die ouerhuis vanuit die erediens na die erediens toe verrig word, en dan sal die Kerk moet vasstel of sy Kategese dikwels nie net neerkom op die ken van die Kort Begrip en die doelwit mis om ook te sorg dat die kategese as lewensvormende verkondigingsfunksie die gedoopte tuismaak by die erediens nie.

\section{GEVOLGTREKKING:}

(a) Die materiaal wat die kategese hanteer is by ouer en Kerk dieselfde.

(b) Die lewensvormende karakter van die Kategese sal in die onderrig van Kerk en doopouer groter prominensie moet ontvang.

(c) Die Kategese van die Kerk sal nooit die van die doopouer kan vervang nie, dit sal mekaar sinvol moet aanvul, vanuit die EREDIENS alleen.

\section{LEERSTOF IN DIE KATEGESE:}

Die werkwoord KATECHEIN kan beteken: Om noukeurig onderrig te gee. Kategese wil daarom nie na willekeur behartig word nie maar streng volens Bybelse opdrag. Omdat dit 'n gestalte van EEN kerklike verkondiging is, sal dit REG moet geskied, omdat God alleen deur die regte verkondiging geloof wil bou en verstrek.

In Artikel XVII van die Kerkwet word die omvang van die kategetiese stof as volg bepaal:

„Bybelse geskiedenis,

Die leerboek van die Kerk,

Die Kerkgeskiedenis".

(i) Die Bybel:

Die kennis van die Heilige Skrif is onontbeerlik vir die geloof. Alleen wanneer ons God ken soos Hy Homself openbaar in Sy Woord, kan ons Hom ook dien soos wat Hy dit van ons verwag. 
Die Kategese as paraliturgiese element van die Kerk se verkondiging wil as hulpmiddel vir die prediking daarom parallel beweeg met die prediking, om die gedoopte toe te rus vir die verstaan en glo van die WOORD.

Uit 'n aantal Skrifsitate'1) blyk dit duidelik dat die Bybelse geskiedenis geleer, ingeskerp, ondersoek en nagevors moet word.

Die een wat onderrig, moet opdrag hê van God om te verkondig en te onderrig en moet vertroud wees met die inhoud van die Skrif. ${ }^{12}$ )

Hieruit is dit duidelik dat die oordrag van die Bybelse boodskap aan die gedoopte 'n verantwoordelike werk is.

\section{Gebruik van die Bybel by die Kategese}

Die vraag kan gestel word of die Bybel self nie in die praktyk van die beoefening van die kategese wederregtelik 'n ondergeskikte of verkeerde plek toegeken word nie.

Die Bybel kom as gevolg van verskillende aksente nie tot sy reg in die kategese nie:

(a) Die Spiritualistiese aksent wat in die kategese 'n persoonlike en gemeenskaplike geestelike lewe wil opbou. Alles word in die kategese gerig op die leiding en werking van die Heilige Gees. „Dan gaat het in die catechese om de bevordering van de vroomheid en is het de bedoeling om de Kerk als gemeenschap de vrome heiligen uit een devote jongere generatie aan te vullen." ${ }^{13}$ )

(b) Die Rationalistiese aksent wat navore kom in die 19de eeu toe die skool sterk navore kom. In die volkstaal het Kategese "de lering" ${ }^{14}$ ) geword en het die klem op memorisering en opsê van betrokke gedeelte neergekom. Die opsê van die Kategismus is nog geen waarborg vir kennis van die Skrif nie, 'n misbruik wat in ons Kerk aandag vra.

(c) Die Moralistiese aksent wil in die kategese die gedagte navore bring dat die taak van die kategeet eintlik daarin bestaan om goeie mense te kweek. By hierdie aksent bestaan die gedagte dat Jesus 'n modelmens was en dat die kategese sulke modelmense moet kweek. Die regte gebruik van die Bybel vrywaar die kategeet egter van die gebruik van sedepreke.

11) Deuteronomium 6:7; 1 Petrus 1:10; Matt. 28:19.

12) Lukas 1:3; 1 Petrus 1:11.

13) Handboek voor de Praktische Theologie - Catechetiek. bls. $287-$ Dr. S. F. H. J. Berbelbach van de Sprenkel, Nijkerk, 1951 Callenhach.

14) Catechetiek bls. 288. 
Willekeur sal by die gebruik van die Bybel nie kan opgaan nie. Die kategeet sal moet weet dat die Bybel in geheel 'n organisme, openbaring van God is. Dat ,geloof 'n sekere kennis van God en Sy beloftes is", kan alleen deur die Bybel as kennisgrond bekom word. Daarom is dit onontbeerlik dat die Heilige Skrif as (geheel) openbaring van God moet ooplê met sy volle inhoud, soos tussen homileet en gemeente by die prediking; sielsorger en lidmaat by die huisbesoek, so ook moet dit ooplè tussen kategeet en katkisant.

As die Kerk wil toesien dat die katkisant met vrymoedigheid ,ja" kan antwoord op die belydenisvraag na die geloof in die Drie-Enige God, sal die katkisant die Bybel moet ken.

(ii) Die leerboek van die Kerk:

Die Kerk aanvaar die Woord van God maar sê ook hoe die Bybel verstaan en geglo word in die belydenisskrif. Niemand kan maar die naam van Jesus Christus bely en glo soos hy wil nie. Ons glo in Hom soos die Kerk en saam met die Kerk. Die belydenis is uitgedruk in die 3 Formuliere van Enigheid.

Die Kerk beskou dit tereg as belangrik en uiters noodsaaklik dat die gedoopte in die Kcrk nie slegs 'n kennis van die Bybelse geskiedenis sal hê en moet hê nie, maar daarmee saam moet hy ook weet hoe hy saam met en soos die Kerk hierdie openbaring van God moet interpreteer en verstaan. Want die godsdiens is nie 'n saak van willekeur of eie oortuiging nie maar 'n saak van diep afhanklikheid aan die cen Bybelse openbaring.

Die belydenis wil hierdie openbaring nie bedek nie; dit kom juis uit hierdie openbaring voort.

In die geloofs- en sedeleer gaan dit daarom om die dinge wat ons moet glo en die lewe wat by daardie geloof pas. Om dus met 'n rein gewete ,ja" te kan sê op die 2de belydenisvraag:

„Het u vir u ook voorgeneem on deur Gods genade by hierdie belydenis te bly, die sonde te versaak en 'n Christelike lewe te lei!" -

moet elke katkisant tenminste 'n gangbarc kennis van die belydenis van die Kerk hê.

\section{(iii) Kerkgeskiedenis in die kategese:}

Vir die gelowige is Jesus Christus die sin en doel van alle geskiedenis. Die ganse geskiedenis is deur God gelei en gestuur na 'n bepaalde punt in die geskiedenis waar God ingedaal het in die tyd in Jesus Christus. Vanaf Sy koms stuur die geskiedenis weer of op Sy wederkoms. Vir die gelowige is alles daarom wat 
$m_{\text {. }} \mathrm{t}$ die mensdom gebeur nie tosvallig nie maar deur God beskik. In die geskiedenis leer ons die gebeure van die verlede ken en hoe daardie gebeure die hede beinvloed.

Uit die Kerkgeskiedenis leer ons die pad ken waarlangs God Sy Kerk op aarde telkemale bshoed, bewaar en gelei het, en hoe die Kerk deur die eeue heen in die wêreld gewerk en geleef het in die gelooî.

Uns leer ook hieruit die aanslae wat op die Kerk gemaak is en hoe die Kerk hierdie aanslae moss afweer. Ons leer ook hieruit die antwoord wat die Kerk mo:s gee ten opsigte van vrą aan die Kerk.

Ons leer hipruit ook die foute van die Kerk. Ons leer ook hoe die Kerk geseënà gegroei het onder die verkondiging van Gods Wcord

Die Kerk se geskiedenis is daarom onontbeerlik omdat dit die weg van die Kerk is na die voleinding toe, onder leiding van die Hoilige Gees wat die Voleinder van die geloof is.

Elke mens wat daarom in die Algemene en Vaderlandse Kerkgeskiedenis behoorlik onderrig is, sal met vreugde by sy belydenis kan sê: „Ek belowe om saam te werk . . ."

\section{GEVOLGTREKKING:}

(a) In die Kerkgeskiedenis was die bestaan van ander wêreldgodsdienste nog altyd 'n feit. Nou ontstaan die vraag of die katkisant nie ook in hierdie verband onderrig moet word en of hiervoor in die Kerkwet nie behoorlike ruimte moet wees nie.

R. Bijlsma ${ }^{13}$ ) sê in hierdie verband: „Van fundementele bətekennis is verder met name, dat de opgroeiende jeug van de kerk sich in de ontmoeting van het Christendom met de ander godsdienste een antwoord gaat vormen op de vraag waarom de keuse van hun leven by Christus valt en waar ten diepste het verskil legt tussen het Christendom en de andere grote religies. Hier kan het een wcsenlike hulp betekenen, dat gesien word hoe overal elders de weg van beneden naar boven wordt bewandeld, terwyl in het Christendom de weg loopt van bove naar beneden."

(b) Omdat in die Kerkgeskiedenis ook die verhale van dwaling, kettery en afval bemerk word, herinner die Kerkgeskiedenis ook aan die Sektewese. As die Kerk daarvan oortuig is dat sy lidmate ten opsigte van die dwaling van die sektes beter toegerus moet wees, behoort dit in die Kerk seker oorweeg te word om in die Kerkwet te bepaal dat die katkisante oor die dwaling van die sektes onderrig moet word.

ij) R. Bijlsma, Kleine Catechetiek, C. F. Callenbach N.V. - Nijkerk 1962. hls 163 . 
(c) Verder kan die vraag ook gestel word of 'n beter toerusting nie nodig is vir die katkisant oor die inhoud van die Kerkwet wat die lewe van die gelowige wil reël en orden ooreenkomstig Gods Woord nie.

(d) In verband met die inhoud ${ }^{16}$ ) van die Kerkboek en kennis van en oefening in die sing van die Psalms en Gesange, hoewel hieromtrent bepalings bestaan, is die skreiende onkunde sekerlik cok' $n$ vraagteken oor die volledigheid in die behartiging van ons kategese.

Omdat die kategese sy plek vind tussen erediens en erediens is Psalms en Gesange, die formuliere en gebede van die Kerk noodsaaklike kennis, daar dit juis direk betrekking het op die erediens. As daar betekenis van die erediens vir die lidmaat duidelik word, sal hulle ook reg verstaan watter verband die bywoning van die erediens met die geloofsbelydenis het.

\section{AMPTELIKE KONTROLE OOR DIE INHOUDELIKE VAN DIE LEERSTOF:}

Dit is duidelik dat die inhoud van die leerstof amptelik bepaal en voorgeskryf kan word in die orde van die Kerk. Maar of die korrek-bepaalde stof wat behandel moet word tereg kom in die beoefening van die kategetiese arbeid is 'n dringende vraag waarvan die antwoord belangrik is.

In die „Kerkwet Atikel 5”, word die „Kategese” en die „afneem van die Openbare belydenis van die geloof", as ampstaak van die predikant gestel. In hierdie selfde Artikel word die,opsig oor . . . die gemeente", en die ,mede verantwoordelikheid met die herder en leraar vir die bediening van die Woord en vir die kategetiese onderwys" as opdrag van die ouderling gestel. ${ }^{1}$ )

Hieruit blyk dat die amptelike reëling in verband met tyd, plek en persone wat die kategese behartig, berus by die Kerkraad. Die opsig oor die regte inhoud van die kategese berus daarom netsoos die toesig oor die prediking by die Kerkraad.

Die predikant sal in sy bediening van die Woord wat altyd ook weer 'n kategetiese karakter dra (bv. by die kategismusprediking), omdat hy daartoe geroep en daarvoor toegerus is, ouer en kerkraad en gemeente moet toerus met die regte begrip oor die kategese. Die erediens word daarom vir elkeen 'n geleentheid waar die voorsorg en nasorg op die verantwoordelikheid van die kategete gedoen word.

16) Kerkwet, Artikel 93 van die bepalings 2(c) en (e) bls. 52.

ii) Kerkwet, Artikel 5 bls. 2. 
Die predikant het daarom die geleentheid om in die uitleg en toepassing van die Heilige Skrif ook die inhoudelike van die kategetiese stof navore te bring. Doopouer en ouderling het daarom die erediens elke Sondag as onontbeerlike toerustingsgeleentheid vir hulle kategetiese taak in die week.

Die predikant het verder die geleentheid van die sielsorg om verder uit te lê, om vanuit die gebeure van die erediens verder te verkondig die betekenis van die doop, die sin van die dooponderrig en te sorg dat in sy verkondiging die samehang van ouer en kerk se kategetiese opdrag glashelder navore sal kom.

In hierdie verband het die ouderling wat die opsig moet uitoefen oor die behartiging van die kategese 'n belangrike funksie om te vervul. Die kerklike opsig strek hom uit ook oor die inhoud van die kategese. Omdat die kategese 'n verkoncigingsgestalte van die Kerk is, sal die inhoud daarvan korrek moet wees omdat dit ,geloof" wil leer aan die gedoopte.

Netsoos die opsig van die ouderling oor die leer van die predikant sal sy opsig hom moet uitstrek oor die inhoud van die kategese aan die gedooptes by die Kerk en in die ouerhuise, op Sondag en in die week.

Om dit te kan doen, sal die ouderlinge in ooreenstemming met die formulier vir die bevestiging van ouderling en diaken ${ }^{18}$ ) verplig wees: „om die Woord van God ywerig te ondersoek en hulle gedurig te oefen in die oordenking van die verborgenhede van die geloof." Verder het die ouderling amptelik die geleentheid om in die erediens, die gesprek in die sielsorg van die predikant, die ouderlingsvergadering en die kerkraadskategese die geleentheid hê om voortdurend vir hierdie taak toegerus te word. Eers nadat self oor die inhoud vir die kategetiese stof sekerheid gekry is deur die ouderling word sy opsig oor die inhoud van die kategese in die gemeente en ouerhuis moontlik. Hoe moet die ouderling dit doen?:

(i) By die amptelike kategese kan die ouderling hierdie verantwoordelikheid behartig deur die kategese self te onderneem en gebruik te maak van die taegeruste kategete wat die kerk wil laat oplei, met die voorgenome kategete-diploma.

(ii) By die huisbesoek waar opsig oor die lewe van die gemeente uitgeoefen word, kan die ouderling maklik kennis neem van die inhoud van die dooponderrig deur die ouer. As die inhoud ontoereikend is, kan toerusting deur die ouderling en predikant by huisbesoek uitgebrei word en leiding gegee word van hoe die kategetiese stof „reg” aangebied moet word.

1s) Formulier vir bevestiging van Ouderlinge en Diakens, Kerkboek, bls. 171. 
(iii) As die ouderling in sy opsigtaak almal (ouer en kind) vergader rondom die Woord by die erediens en sorgdra dat die feitekennis bygebring word vir die gedoopte, dat hierdie feite se betekenis verklaar word, dat hierdie kennis kontraleer word, en dat die feite met betrekking tot al die voorgaskrewe stof verstaan is, dan het dic volle omvang van die Evangelie tot stigting van die geloof aan die gedoopte bekend geword en die opstigtaak van die ouderling is dan sinvol verrig.

\section{Gevolgtrekking:}

(a) As dit in aanmerking geneem word dat die predikant sekerlik die beste toegeruste persoon in elke gemeente is om die Skrif en die leer van die Kerk die beste te kan uitlê en tospas, dan lyk dit 'n voor die handliggende eis dat die pradikant die kategese met die oog op die openbare geloofbelydenis self moet waarneem, ten einde die katkisant se feitekennis te orden $\epsilon n$ in ' $n$ verstaanbare en planvolle samehang aan die katkisant bekend en verstaanbaar te laat word.

(b) Dit lyk of die beste broefening van die kontrole oor die inhoudelike van die ka ${ }^{\perp}$ egetiese stof, langs die bestaande weë van sielsorg en opsig die beste implementeer kan word in die praktyk.

\section{IS NASORG AAN DIE DOOPOUERS NODIG?}

Die doopkategese rorm in die praktyk die voorspel op die doopgeleenheid ca vil claarom dien as voorkoming van misverstand met betrekking tot die doop en as uitleg van die doop wat die implikasies van die dooponderrig duidelik wil stel.

Omdat die dooponderrig egter 'n veeleisende en omvattende implikasie het vir elke doopou 2 , die kennis dikwels ontoereikend is, sal die sielsorger as verkondiger en Kerkraad as opsighoudende liggaam voortgaande sorg of nasorg ten opsigte van elke cloopouer moet uitoefen.

In hierdie nasorgwerk sal die Kerk daaivoor moet sorg dat:

(i) die doopouer sy eie verbondenheid en die van sy gedoopte kind aan die erediens sal verstaan.

(ii) Die doopouer self lewend moet glo om geloof aan sy kind te kan leer met woord en daad.

(iii) Die doopouer sal, totdat dit weer Sondag word, in gebed bid en luister na Gods Woord, moet lewe saam met die gedoopte kinders.

(iv) Die week tussen Sondag se erediens en volgende Sondag mag vir die doopouer nie planloos verbygaan nie. Die huisgods- 
diens sal daarom nie in die week vir die gesin kan beteken 'n paar liefling-skrifgedeeltes wat fragmentaries as „mooi" sede'esse of moraalpreke uit die Bybal golees word nie. Want kategese beoog in die ecrste plek geloof en nie perfekte moraal of sede nie.

(v) Die verwagte perikope-indeling behoort mee te help om in hierdie nasorg op die doop goed te kan kontroleer. Indien die kategese-rooster en die Bybelse dagboek en die inrigting van die kategismus-prediking nouer verband het, sal só die nodige materiaal vir die ouer planvol in die hand gelê word om die kategese gedurende die week te kan behartig.

\section{BESLUITE VAN DIE KERK VANAF 1961-1967 EN ENKELE KONKLUSIES:}

In die lig van wat reeds gesê is, is enkele besluite van die Kerk in hierdie verband belangrik.

(a) By $1961^{19}$ ) se Algemens Kerkvergadering is besluit: „Die vergadering beveel aan dat waar enigsins moontlik, die belydeniskatcgese op vaste tye gedurende die week sal geskied en dat minstens twee uur per week hieraan bestee sal word."

Die sin van hierdie besluit lê daarin dat die Kerk die plek van die kategese sien, op pad vain dic een crediens na die volgende erediens, en dan hoort dit ook daar tuis waar die gemeente gedurende die week werk en lewe om ook daar vormend in t. werk op die lewe van die gemeente. Elke Kerkraad wat onnodige verskonings aanvoer om nie hierdie 2 uur per week te kan inruim vir die kategese nie, berokken 'n ernstige skade aan die behartiging van hierdie uiters belangrike verkondigingsgestalte van die Kerk.

(b) In 1961 is verder besluit: „Die vergadering beklemtoon die taak van die predikant ten opsigte van kategese wat weekliks waargeneem moet word.":") (Vergelyk beroepsbricf en betrokke bepalings in die Kerkwet).

Om die belangrikheid van dic predikant as kategeet ts onderstreep is hierdie besluit ' $n$ baie duidelike heenwysing na die toerusting van die predikant wat hom by uitneməndheid geskik en toegerus bevind vir hierdie taak. Die besondere bydrac wat die predikant sekerlik kan maak in elke gemeente, is om kerkraad en doopouers toe te rus vir hulle kategetiese verantwoordelikheid. Hierdie toerusting is miskien ten opsigte van die

19) Notule A.K.V. 1961, bls. 26.

2ii) Notule A.K.V. 1961, bls. 25. 
katkisante wat môre en oormôre die ouderling en doopouer word, die beste uit te voer, gesien die bogenoemde besluit, dat dit weekliks MOET geskied.

(c) In 1961 en later is die saak van 'n vasgestelde ouderdom vir die openbare geloofsbelydenis onder bespreking gebring. In die Kerkwet ${ }^{21}$ ) word bepaal: „Tot die openbare belydenis van die geloof word persone wat hiervoor voorberei is, deur die Kerk €n vanaf min of meer sestienjarige leeftyd toegelaat."

Omdat 'n ouderdomsgrens in die Kerk geen waarborg is vir behoorlike voorbereiding ten opsigte van die kategese nie, behoort so 'n bepaling uit die Kerkwet te verdwyn, sodat kerkrade hulle eie diskresie in hierdie verband kan handhaaf in verantwoordelikheid.

(d) In 1964 is in verband met die wese van die Sondagskool":-) 'n belangrike besluit en rigting in die Kerk herbevestig. In opvolging van vorige besluite om die kategese los te maak van 'n skoolse atmosfeer en dit onlosmaaklik by die erediens te betrek, is hierdie denkrigting deur die Kerk aanvaar. In opdrag van hierdie Algemene Kervergadering is die Raad vir Sondagskool en Kategese besig om die praktiese implikasies van hierdie standpunt uit te werk vir toepassing in die Kerk. As gevolg van hierdie ingeslane weg, lyk dit noodsaaklik dat die Kerk sy terminologie in hierdie verband in hersiening moet neem. In die Kerkwet se bepalings vir die kategese en op ander plekke in die Kerkwet word die woord Sondagskool nog baie keer aangetref en in die terminologie wat in die gewone omgangstaal in die Kerk gebruik word, word Sondagskool nog meer gebesig as kategese wat 'n bruikbaarder Bybelse woord is.

In hierdie selfde verband lyk dit of die terme jeugdiens of kinderkerk nie meer opgaan nie. Om die gemeente horisontaal te verdeel in oues en jonges, volwassenes en onvolwassenes, berus op 'n misvatting dat die Heilige Gees te swak sou wees om nie ook vir die kind in die erediens geloof te skenk, waar Gods Woord reg gepreek en die Sakramente bedien word volgens die instelling van Christus nie.

(e) Met die groeiende onkerklikheid van ons mense sal die belydeniskategese met die mense te doen kry wat nie gedoop is rije en ook geen godsdienstige opvoeding gehad het nie.

By hierdie mense kan nie kennis van die Woord veronderstel word nie. Volgens die eis van Hoofstuk 9, Art. 91 en 92 sal

21) Artikel 93(1) van die Bepalings.

22 A.K.V. Notule 1964, bls. 158. 
hierdie mense die voorbereidende, gewone en belydeniskategese agteenvolgens moet deurloop. Dit sou onbillik wees om hierdie groepering by een van genoemde groepe te probeer inskakel, en so 'n inskakeling is buitendien tot mislukking bestem.

Daar ontstaan dus die vraag na die plek van 'n missionerende kategese, wat dan moet uitloop op die geleentheid van doop en belydenis van die geloof.

(f) Ten slotte, daar dit hoofsaaklik gegaan het oor die kategese met die oog op belydenis van die geloof, wil ons enkele dinge opmerk ten opsigte van die geleentheid waar katkisante formeel toegelaat word tot die openbare belydenis van hulle geloof. Die kerk behoort in hierdie verband ook duidelik rekenskap te gee van wat die korrekte praktyk sou wees.

Die volgende word ter oorweging gestel:

(i) Die belydeniskategese word deur 'n kommissie van die Kerkraad gedeligeer maar die beslissing tot toelating as sodanig kan nie aan 'n paar lede van die Kerkraad oorglaat word nie.

(ii) So 'n geleentheid van toelating tot die openbare belydenis van die geloof behoort deur die Kerkraad, gemeente en ouers bygewoon te word.

(iii) By so 'n geleentheid behoort die katkisante in die openbaar ondervra te word. Hierdie ondervraging behoort op taktvolle wyse te geskied en kan daarop gemik wees om vas te stel in hoe 'n mate die kennis wat opgedoen is by die kategese die lewe en gesindheid van die katkisante gevorm het. Daarna neem die Kerkraad 'n amptelike besluit.

(iv) Die formulier vir die bevestiging van lidmate is ontoereikend. Kan by hierdie geleentheid mense in die verbond van die genade bevestig word, as dit reeds geskied het by die bediening van die heilige doop?

(v) Die ou ,wegwys" praktyk word bevraagteken by die finale ondervraging. Die siftingsproses behoort vooraf plaas te vind. 